\title{
一般口演 4
}

\section{舌骨上筋群の表面筋電位を用いた舌運動の識別とその可視化法}

\author{
Classification and visualization method of tongue motions \\ using EMG signals of suprahyoid muscles \\ ○佐々木誠 ${ }^{1)}$, 大西康平 ${ }^{1)}$, 中山 淳 $^{2)}$, 柴本 勇 $^{3)}$, 鎌田勝裕 ${ }^{4)}$ \\ Makoto Sasaki ${ }^{1)}$, Kohei Onishi ${ }^{1)}$, Atsushi Nakayama ${ }^{2)}$, Isamu Shibamoto ${ }^{3)}$, Katsuhiro Kamata ${ }^{4)}$ \\ 1) 岩手大学大学院工学研究科 \\ 2) 一関工業高等専門学校制御情報工学科 \\ ${ }^{3)}$ 国際医療福禅大学保健医療学部 \\ 4) 株式会社パターンアート研究所 \\ ${ }^{1)}$ Iwate University \\ ${ }^{2)}$ Ichinoseki National College of Technology \\ ${ }^{3)}$ International University of Health and Welfare \\ ${ }^{4)}$ Pattern Art Laboratory Co., Ltd.
}

I. 目的

平成 23 年度に，肺炎が我が国の死因第 3 位となった。 肺炎による死亡者のうち 9 割以上が高齢者で, その約半 数は嚥下障害による誤嚥性肺炎が原因とされている。ま た， 75 歳以上の高齢者の $30 \%$ に嚥下障害があると言わ れており，国内の患者数は少なくとも $70 \sim 80$ 万人が見 積もられている。高齢化社会に直面した我が国におい て,このように深刻化した曣下障害への対応は急務であ る.

嚥下障害のリハビリテーションには，食べ物を用いた 直接的な訓練と, 食べ物を用いない間接的な訓練があ る.このうち, 間接訓練の一つに, 舌を左右上下に突き 出す, 口蓋に押し付けるなどの様々な舌運動によって, 舌の可動域, 筋力, 協調性, 食べ物の移送機能などの改 善を図る舌運動訓練がある ${ }^{1)}$ 。しかしながら, 舌運動訓 練は単調であるうえ, 訓練効果を定量化し, 本人へ提示 することが難しいため, 本人のやる気を維持しつつ継続 的に訓練を実施することは困難である。そこで著者ら は, 舌の訓練動作で PC 上のゲームを操作し, 楽しく遊 びながら讌下機能の改善と, 訓練効果の定量化を行う新 しい訓練支援システムの開発を進めている ${ }^{2)}$.

本研究では, 舌骨上筋群の EMG 信号から舌の訓練動 作や燕下動作を識別し, リアルタイムにその状態を可視
化する手法を提案する。

\section{II. 方 法}

\section{1. 舌運動の識別法}

1) 被験者

被験者は, 舌の運動機能が正常な健常成人男性 5 名 $(22.2 \pm 1.3$ 歳, $169.7 \pm 7.4 \mathrm{~cm}, 61.0 \pm 11.3 \mathrm{~kg}$, mean \pm SD）とした.

\section{2) $\mathrm{EMG}$ 計測}

舌骨上筋群の EMG 信号を計測するために，フレキシ ブル基板を用いて開発した 22 チャンネルアクティブ電 極を，各被験者の顎下部に貼り付けた。また，アース電 極とアクティブコモン電極を，耳クリップを用いて左右 の耳㭼に取り付けた。そして，22チャンネルアクティ ブ電極を構成する各電極とアクティブコモン電極との電 極間電位差を，差動増幅器を用いて 2,052 倍に増幅した 後, サンプリング周波数 $2,000 \mathrm{~Hz}$ で PCに取り达んだ。

計測した舌の訓練動作は，口を開いた状態で舌先を 右，左，上，下へと口腔外に突き出す 4 動作，ならびに 唾液嚥下の合計 5 動作とした。舌の動作時間は約 2 秒と し，各動作の間に2 秒の安静時間を設けた。計測回数は 5 動作×14セットとした。 


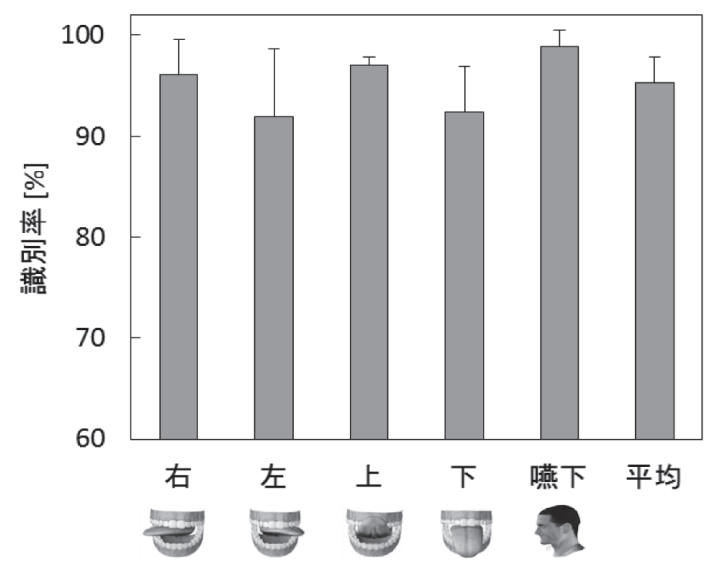

図 1 EMG 信号を用いた舌運動の識別精度

\section{3 ）識別方法}

22 チャンネルの EMG 信号から，振幅に関する特徵量 Root mean square (RMS) と, パワースペクトルの包絡 形状に関する特徵量 Cepstrum coefficient (CC) をそれ ぞれ抽出し, 特徵べクトルを構成した。 その後, パター ン分類器の一つであるサポートベクターマシン (SVM) を用いて, EMG 信号の特徵ベクトルから各動作を分類 する識別関数を, 被験者ごとに作成した。識別関数の作 成には, 14 セッの $\mathrm{EMG}$ 計測データのうち, 最初の 4

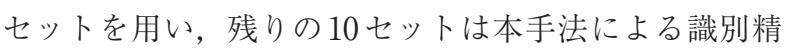
度の評価に用いた。

\section{2. 舌運動の可視化法}

舌運動を可視化するために, 3 次元 CG ソフトウェア (Poser 9, Smith Micro Software Inc.) を用いて, 舌モデ ルを作成した。さらに, Visual Studio 2008 Professional Edition（Microsoft Co., Ltd.）を用いて，舌モデルをマ ウス操作によってリアルタイムに制御するためのソフト ウェアを作成した。

実験では，舌運動の識別実験と同様に，舌先を右，左， 上，下へと突き出す 4 動作，ならびに唾液嚥下の合計 5 動作を 4 セット計測し, SVM による個人データの学習 を行った。 その後, 舌骨上筋群の $\mathrm{EMG}$ 信号から識別し た舌先の向きを, DAQ ユニット (USB-6218, National Instruments Co. ) と入力支援装置（らくらくマウス II Wireless, KoKoTo STEP) を用いて, 左右上下方向に 対するマウスポインタの移動に対応付けた。また，嚥下 動作は, 約 1 3 分に一度の頻度で無意識に行われるた め, ノイズキャンセルという位置付けで, マウス操作と の対応付けは行わなかった。このような条件のもと, 被 験者の舌の動作に応じて, 舌モデルをリアルタイムに制

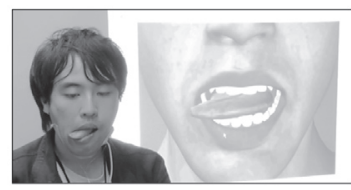

(a)右動作

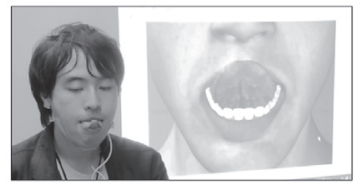

(c)上動作

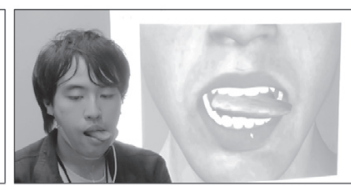

(b)左動作

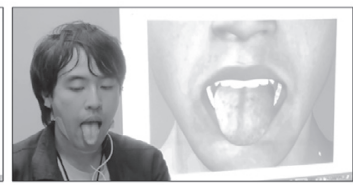

(d)下動作
図 2 EMG 信号を用いた舌運動の可視化

御できるかどうか, 実験により検証を行った。

\section{III. 結果及び考察}

\section{1. 舌運動の識別結果}

被験者 5 名に対する全 5 動作の識別精度の平均值と標 準偏差を図 1 に示した。いずれの動作も $92 \%$ 以上の識 別精度を示し， 5 動作の平均では $95.3 \pm 2.6 \%$ となった。 舌骨上筋群は，舌の形状や位置を直接的に制御する筋で はなく，舌運動に応じて舌骨の位置を適切に制御する筋 であるが, 本結果より, 舌骨上筋群の $\mathrm{EMG}$ 信号から, $95 \%$ 以上の精度で舌の訓練動作や喠液嚥下を識別できる ことが示された。

\section{2. 舌運動の可視化結果}

舌骨上筋群の $\mathrm{EMG}$ 信号から舌の訓練動作を識別し, その状態を可視化した結果を図 2 に示した。図中の左側 が実際の舌運動，右側が舌のアニメーションの様子であ る。この結果, 内舌筋により制御される複雑な舌の形態 までは詳細に再現することはできなかったが, 被験者が 行った舌の訓練動作を舌骨上筋群の EMG 信号からリア ルタイムにアニメーション表示できることは示された。 今後は，本手法を利用したリハビリテーション支援や訓 練効果の評価法について更なる検討を行う予定である.

\section{N. 参考文献}

1) J.A. Logemann. Evaluation and treatment of swallowing disorders. 2nd ed., Pro-Ed, Austin, TX, 1998.

2 ) Sasaki M, et al. Tongue Motor Training Support System. Proc of IEEE EMBC' 14 2014; 3582-3585. 